\title{
Quantitative assay for the detection, screening and reactivity evaluation of nanoceria particles
}

Ali Othman, Kristen Bear and Silvana Andreescu*

Department of Chemistry and Biomolecular Science, Clarkson University, Potsdam, New York 13699-5810, USA.

E-mail: eandrees@clarkson.edu;

Fax: +(315) 268 6610; Tel: +(315) 2682394 


\begin{abstract}
Increasing use of engineered nanoparticles (NPs) in many industrial processes and consumer products requires rapid analytical methodologies to reliably detect and screen samples for the presence of NPs. Here, we report the development, analytical characterization and performance evaluation of a colorimetric assay as a comprehensive test for quantitative detection, screening and reactivity evaluation of nanoceria (cerium oxide, $\mathrm{CeO}_{2}$ ) particles in aqueous environments. We provide a critical discussion of the role of environmental conditions including $\mathrm{pH}$, ionic composition, and presence of humic acid and particle type on the overall performance and sensitivity of this assay. The method is based on the strong oxidation ability of nanoceria for organic dyes such as 2,2'-azino-bis(3-ethylbenzothiazoline-6-sulphonic acid) (ABTS) and 3,3',5,5'-tetramethyl-benzidine dihydrochloride hydrate (TMB). Performance characteristics were established with a series of commercially available NPs of varying sizes dispersed in different environments. The results demonstrate that colorimetric assays can be used as a rapid and cost effective way to characterize nanoceria. The method enables identification and selective detection of nanoceria among other metal oxides including $\mathrm{Fe}_{2} \mathrm{O}_{3}, \mathrm{TiO}_{2}, \mathrm{Sb}_{2} \mathrm{O}_{3}, \mathrm{ZnO}, \mathrm{SiO}_{2}$, and $\mathrm{Al}_{2} \mathrm{O}_{3}$. Applicability of the method for detection of nanoceria in environmental water samples is demonstrated. Recommendations are provided on the selection of the reaction conditions to ensure validity and reliability of measurements. The assay offers an effective and inexpensive alternative to advanced spectroscopic instrumentation, as a screening assay for nanoceria in environmental water. The method can be used as a general tool for the analytical characterization of redox active nanomaterials.
\end{abstract}

Keywords: nanoceria $\cdot$ nanoparticle detection $\cdot$ metal oxide selectivity $\cdot$ colorimetric assay 


\section{Introduction}

Cerium oxide $\left(\mathrm{CeO}_{2}\right)$ NPs, or nanoceria are extensively investigated in a large number of applications, as polishing agents in the semiconducting industry, as a fuel additive in diesel particulate filters to reduce toxic emissions [1-4], and more recently as therapeutic agents in biomedicine, and as materials for sensing probes, sorbents and electrochromic coatings. As a result of these applications, nanoceria can be found in a variety of environments where they can interact with and affect biological and environmental processes. Nanoceria can participate in redox reactions, act as a sorbent for toxicants or interact with a variety of environmental and biologically-significant constituents [4-6]. Several studies have reported that these particles can be inhaled causing adverse pulmonary effects [4], induce inflammation [1,2] and promote oxidative stress in a variety of cell lines and model organisms, or can be bio-transformed and internalized by plants $[7,8]$. Therefore there is a risk that these NPs may cause health, ecological and environmental effects, and there is a need to quantify exposure levels in environmental and biological systems. However, in spite of the increasing use of these NPs and the knowledge of their potential effects, few analytical methodologies exist to rapidly detect presence and concentration of nanoceria.

General methods to characterize NPs include conventional transmission electron microscopy (TEM) and scanning electron microscopy (SEM) for size and shape, dynamic light scattering (DLS) and $\zeta$-potential analysis for hydrodynamic properties (e.g. agglomeration, surface charge), powder X-ray diffraction (PXRD), X-ray photoelectron spectroscopy (XPS) [9], Fourier Transform Infrared (FTIR) and Raman spectroscopy to determine chemical composition, surface coatings, particle size, crystallinity and surface area. AFM analysis can also be used in conjunction with TEM and SEM to assess particle size [10, 11]. Atomic absorption (AAS), atomic emission (AES) and inductively coupled plasma mass spectrometry (ICP-MS) can be used to determine elemental composition. While powerful, these methods are expensive, time consuming and require specialized instrumentation. Therefore, only a few numbers of samples can be analyzed.

In previous research, color based detection was demonstrated for monitoring the catalytic activity of different types of metal and metal oxide NPs using a soluble organic dye, methylene blue, and a reducing agent, sodium borohydride [12] but the method showed color response to a 
large variety of NPs and therefore lacked selectivity. Herein, we report development and performance characterization of a colorimetric assay with tailored selectivity for detection of nanoceria. The method is based on the oxidation ability of nanoceria for organic dyes such as ABTS and TMB, which develop concentration-dependent color changes in presence of nanoceria. Selectivity is enabled by the unique and characteristic redox properties of nanoceria due to the co-existence of the Ce(III/IV) states at the NP surface which provides a distinctive reactivity pathway against soluble organic dyes when compared to other oxides [13, 14]. While the redox property is a common feature among nanoceria particles, their reactivity varies with the $\mathrm{pH}$, ionic composition and presence of natural organic material, that can affect their surface properties and stability [15-17]. Therefore, knowledge on how these parameters affect the overall performance of these assays is essential for the future development of analytical methodologies for nanoceria detection.

This work describes development and characterization of visual tests for screening of nanoceria particles in environmental water samples. A critical evaluation of the role of environmental constituents and exposure conditions is presented comparatively for two chromogenic indicators, TMB and ABTS. We demonstrate that these assays are generally applicable for detection of a variety of nanoceria particles, and can be used as a screening tool to assess reactivity and detect particle content in environmental water. Since both the reactivity and environmental impact are dependent on the type and dose of NPs, and some change with the exposure and storage conditions, inexpensive and widely accessible tools that can be used to rapidly characterize NPs are highly valuable for environmental detection and epidemiological studies.

\section{Experimental}

\subsection{Chemicals and materials}

Cerium(IV) oxide NPs $\left(\mathrm{CeO}_{2}, 10-20 \mathrm{~nm}\right), 20$ wt. \% colloidal dispersion in $2.5 \%$ acetic acid and 2,2'-azino-bis(3-ethylbenzothiazoline-6-sulphonic acid) (ABTS, 98\%) were purchased from Alfa Aesar. 3,3',5,5'-Tetramethyl-benzidine dihydrochloride hydrate (TMB, 98\%), humic acid (HA, sodium salt $45-70 \%$ technical, and nitric acid $\left(\mathrm{HNO}_{3}, 68-70 \%\right)$ were purchased from Acros. 
Citric acid anhydrous and Tris(hydroxymethyl)aminomethane hydrochloride (Tris-HCl, $\geq 99.0 \%$ ) were purchased from Sigma. Sodium hydroxide, sodium acetate, and acetic acid glacial were purchased from J.T. Baker, and sodium citrate dihydrate $(90-100 \%)$ was purchased from Mallinckrodt Baker, Inc. Silica colloidal $\left(\mathrm{SiO}_{2}, 35 \mathrm{~nm}\right.$, acidic) was purchased from NYACOL nano technologies, Inc. Titanium dioxide $\left(\mathrm{TiO}_{2}, 10-30 \mathrm{~nm}\right.$ ), and zinc oxide NPs ( $\mathrm{ZnO}, 10-30$ $\mathrm{nm})$ were purchased from SkySpring Nanomaterials, Inc. Iron oxide $\left(\mathrm{Fe}_{2} \mathrm{O}_{3}, 20-40 \mathrm{~nm}\right)$, and antimony oxide $\left(\mathrm{Sb}_{2} \mathrm{O}_{3}, 80-200 \mathrm{~nm}\right)$ nanopowders were purchased from US Research Nanomaterials, Inc, where alpha-alumina nanopowder $\left(\mathrm{Al}_{2} \mathrm{O}_{3}, 300 \mathrm{~nm}\right)$ was purchased from SPI Metallography Supplies. All reagents were used without further purification, and all solutions were prepared with ultrapure water (Millipore, Direct-Q system, 18.2 M $\Omega . c m$ ).

To test the applicability of this method for detection of varying types of nanoceria we have tested the following commercially available nanoceria particles: (A) Alfa Aesar, \#40125, $10-20 \mathrm{~nm}$ (20\% in $\mathrm{H}_{2} \mathrm{O}$, colloidal dispersion stabilized in 0.4 M acetate), (B) Alfa Aesar, \#47240, $<5 \mathrm{~nm}\left(20 \%\right.$ in $\mathrm{H}_{2} \mathrm{O}, \mathrm{NP}$ dispersion, high $\left.\mathrm{pH}\right),(\mathrm{C})$ Sigma-Aldrich, \#MKBD9924, <25 nm (10 wt\% dispersion in water, (D) SkySpring, \#2110CG, 10-30 nm, (nanopowder), (E) SigmaAldrich, \#544841, <25 nm (nanopowder). Their characteristics are summarized in Table S1.

\subsection{Solutions and buffers}

Effect of $\mathrm{pH}$ and buffer solutions were evaluated using acetate, citrate, and Tris buffers. The

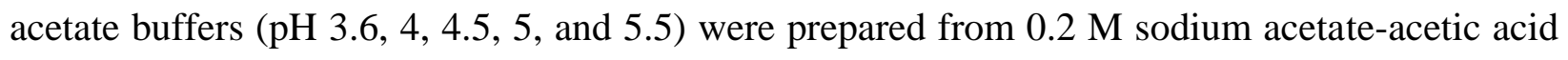

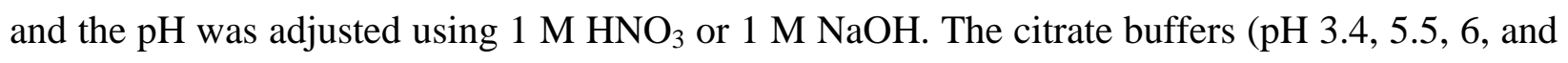
7.4) were prepared from $0.2 \mathrm{M}$ sodium citrate dihydrate-citric acid and the $\mathrm{pH}$ was adjusted using $1 \mathrm{M} \mathrm{HNO}_{3}$ or $1 \mathrm{M} \mathrm{NaOH}$. Tris buffers ( $\mathrm{pH} 7.5,8,8.5$, and 9) were prepared from $0.2 \mathrm{M}$ Tris- $\mathrm{HCl}$ and the $\mathrm{pH}$ was adjusted using $3 \mathrm{M} \mathrm{NaOH}$ in distilled water. The NP dispersion was diluted in deionized water, and sonicated for $5 \mathrm{~min}$ prior to all experiments.

The effect of ionic strength was tested with $\mathrm{NaCl}$ solutions at concentrations ranging from 1 to $1000 \mathrm{mM}$ in deionized water. The effect of $\mathrm{pH}$ and ionic strength were determined for nanoceria at a concentration of $25 \mathrm{mg} \mathrm{L}^{-1}$. To investigate the effect of HA, particles were dispersed in humic acid solutions at concentrations of $1,5,10$, and $50 \mathrm{mg} \mathrm{L}^{-1}$ prepared in deionized water. The effect of ionic strength and HA was determined for ABTS and TMB at 
concentrations of $0.13 \mathrm{mM}$ and $1.3 \mathrm{mM}$, respectively. Solutions of dyes were prepared fresh each day and were stored on ice until use.

\subsection{Application to environmental water samples}

The applicability of this method was evaluated in three different water samples, which were collected from the local Raquette River, Potsdam, NY; Norwood beach, Norwood, NY; and tap water. The water samples were filtered using a $0.2 \mu \mathrm{m}$ syringe filter before use. For analysis, the samples were spiked with a nanoceria at a concentration of $10 \mathrm{mg} \mathrm{L}^{-1}$.

\subsection{Measurement procedure}

Experiments were performed in $1.5 \mathrm{ml}$ cuvettes using UV-Vis spectroscopy. The optimized procedure for the colorimetric measurement consists in the addition of $100 \mu \mathrm{l}$ of $2 \mathrm{mM}$ ABTS or $200 \mu \mathrm{l}$ of $10 \mathrm{mM}$ TMB, to the sample cell containing NP suspension at varying concentrations. The dye was left to react with the NPs until a constant absorbance value was achieved. Experiments to optimize the methodology were carried out with nanoceria dispersions prepared in deionized water.

\subsection{Instrumentation}

UV-Vis spectrophotometric measurements were performed with a Schimadzu UV-2401PC spectrophotometer equipped with a $1 \mathrm{~cm}$ path length cell. Zeta potential $(\zeta$ - potential) was measured at $25^{\circ} \mathrm{C}$ with a Brookhaven Zeta Plus analyzer. A JEOL JSM-2010 instrument was used for high resolution transmission electron microscopy (HRTEM). TEM analysis was performed on aliquots of nanoceria particles placed on a copper HRTEM grid and dried under vacuum.

\section{Results and discussion}

\subsection{Method principle}


The nanoceria colorimetric detection assay is based on monitoring of the oxidation of the organic dyes ABTS and TMB by the NPs. The spectroscopic behaviour of ABTS and TMB in the absence and presence of nanoceria dispersion is shown in Fig. 1. The assay is based on the ability of nanoceria to act as an oxidizing agent for the oxidation of organic dyes [18, 19]. Here we employ for the first time this concept to develop an analytical quantification assay for detection of nanoceria. The nanoceria particles used to optimize the assay have an average diameter of $19.5 \pm 4.3 \mathrm{~nm}$ measured by DLS with a polydispersity of $0.418 \pm 0.195$, also confirmed by HRTEM analysis. Addition of nanoceria dispersion to ABTS or TMB solutions results in a strong visual color change of the ABTS and TMB from colorless to green and blue, respectively. The oxidation product of ABTS is characterized by a new absorption peak at 420 $\mathrm{nm}$, while that of TMB shows two new absorption peaks at 370 and $652 \mathrm{~nm}$. These results indicate that the ABTS and TMB are directly oxidized by nanoceria. The kinetics of the reaction is much faster for ABTS than for TMB. The color change for ABTS was observed within seconds, as compared to minutes for TMB. The difference in reactivity can be due to the difference in surface charge and possible repulsion effects between the NPs and TMB. The particles are positively charged with a measured zeta potential of $(+40.41 \pm 2.8 \mathrm{mV})$ while ABTS is negatively charged and TMB is positively charged. In spite of the charge difference, both dyes are oxidized by the NPs, and can be used to develop NP detection assay based on this principle.

\section{Fig. 1.}

\subsection{Analytical performance characteristics}

In the next set of experiments, we investigated if oxidation of ABTS and TMB is concentration dependent, and if this assay can be used to quantitatively detect NPs. Fig. 2 shows the visual images and the corresponding UV-Vis spectra of the ABTS and TMB solutions in presence of varying concentrations of nanoceria. For both dyes, the color change is linearly dependent on the concentration of nanoceria and varies with increasing NP concentration from colorless to dark green and dark blue for ABTS and TMB respectively. The UV-Vis spectra of both solutions show increasing maximum absorbance peaks at $420 \mathrm{~nm}$ and at $652 \mathrm{~nm}$ upon increasing of NPs concentration, suggesting that the oxidation of ABTS and TMB can be used for NP detection 
purposes. For ABTS, the linear concentration curve ranged from 0.78 to $50 \mathrm{mg} / \mathrm{L}$ with a limit of detection (LOD) and quantification (LOQ) of $183.6 \mu \mathrm{g} / \mathrm{L}$ and $618.5 \mu \mathrm{g} / \mathrm{L}$, respectively. For TMB, the linear range was between 0.78 to $50 \mathrm{mg} / \mathrm{L}$ with a LOD and LOQ of $42.4 \mu \mathrm{g} / \mathrm{L}$ and $141.2 \mu \mathrm{g} / \mathrm{L}$, respectively. These results indicate the capability of the colorimetric assay for detection of nanoceria particles in the ppb concentration range. This detection limit is superior to that of other reported colorimetric assays for NP detection, none of which show selectivity for nanoceria. Table 1 describes the main characteristics of this assay versus other types of colorimetric assays for NP detection reported in literature. To the best of our knowledge this is the first assay using chromogenic dyes for rapid visual detection of nanoceria particles in the ppb concentration range.

Fig. 2.

Table 1.

\subsection{Optimization of operational parameters}

Nanoceria properties and reactivity can change depending upon the environment and can vary with the exposure time and solution chemistry $(\mathrm{pH}$, ionic strength and natural organic matter) $[20,21]$. Therefore, factors such as the reaction time, $\mathrm{pH}$ and particle behavior in the presence of environmental constituents such as salts (e.g. $\mathrm{NaCl}$ ) play an important role in defining the optimum operational conditions of this assay for practical implementation. The influence of these parameters was investigated by means of spectroscopic and zeta potential measurements. To optimize these parameters, measurements were performed at $420 \mathrm{~nm}$ and at $652 \mathrm{~nm}$ which showed the maximum absorbance changes for ABTS and TMB, respectively.

\subsubsection{Reaction time and kinetics}

To study the reaction kinetics, the absorbance changes of the ABTS and TMB upon the addition of nanoceria were recorded for $12 \mathrm{~min}$ for ABTS and $60 \mathrm{~min}$ for TMB. Fig. 3 shows the effect of reaction time on the detection of nanoceria. The reaction is time dependent for both ABTS and TMB dyes. ABTS shows significantly faster reaction with a color change observed within seconds, reaching a plateau after 10 minutes. The reaction of nanoceria with TMB also exhibits a time dependent behavior, but with slower kinetics than ABTS. The color started to develop 
within minutes and increased gradually for about 60 minutes. Further tests with TMB were performed after $15 \mathrm{~min}$ incubation. Experiments with the ABTS assay were performed after 5 minutes incubation time. These results indicate that the reaction time is a critical parameter and must be carefully controlled for ensuring adequate reliability and reproducibility.

\section{Fig. 3.}

\subsubsection{Effect of $p H$ and environmental composition}

$\mathrm{pH}$ and buffer conditions are important parameters for optimizing detection systems involving NPs and organic dyes, as these can change the surface properties and oxidation behavior of the NPs and the dyes. The solution pH plays a critical role on the adsorption processes at the NP surface and also affects the nature of surface functionalities. For example, in aqueous solutions, the surface of nanoceria exists in several hydroxylated cerium species depending on the $\mathrm{pH}$, as: $\mathrm{CeO}_{2} \cdot 2 \mathrm{H}_{2} \mathrm{O}$ [or $\left.\mathrm{Ce}(\mathrm{OH})_{4}\right]$ at $\mathrm{pH}>10, \mathrm{Ce}(\mathrm{OH})_{2}{ }^{+}$and $\mathrm{Ce}(\mathrm{OH})^{2+}$ at $\mathrm{pH}<10$ as well as a number of $\mathrm{Ce}(\mathrm{OH})^{3+}, \mathrm{Ce}(\mathrm{OH})_{2}{ }^{2+}, \mathrm{Ce}(\mathrm{OH})_{3}{ }^{+}$at $\mathrm{pH}<3$. It was established that higher $\mathrm{pH}$ values favor oxidation of $\mathrm{Ce}^{3+}$ to the $\mathrm{Ce}^{4+}$ and the formation of $\mathrm{Ce}(\mathrm{IV})$ compounds. In this process, hydroxyl groups and dissolved oxygen are heavily involved by affecting the oxidation of $\mathrm{Ce}^{3+}$ to $\mathrm{Ce}^{4+}$ [22]. Ionic species present in buffer solutions such as phosphate and citrate can also adsorb to the nanoceria surface forming cerium complexes that can affect particle reactivity and stability. For example, reduced reactivity of nanoceria NPs was reported in phosphate buffer which was attributed to the formation of cerium phosphate on the particle surface [23] resulting in a partial inactivation and blocking of the interconversion between $\mathrm{Ce}^{(3+/ 4+)}$ states at the particle surface.

In this work, we tested three commonly used buffers, acetate, citrate and Tris, at varying $\mathrm{pH}$ values. Particles dispersed in both acetate and Tris buffers form visible whitish suspensions and possible aggregation or conversion to hydroxylated amorphous compounds before addition of the organic dye (Fig. S1 in the Supplementary Information (SI)). The process is more pronounced in acetate at $\mathrm{pH} 5$ and 5.5, and in Tris for $\mathrm{pH}$ values ranging from 7.5 to 9.0. This indicates that simply dispersing the particles in buffer solutions affect their colloidal stability. Fig. 4 displays the effect of $\mathrm{pH}$ and buffer conditions on the detection of nanoceria using the ABTS and TMB dyes. The colorimetric images and the UV-Vis changes at the maximum absorbance of the dyes as a function of $\mathrm{pH}$ show a general decrease from acidic to basic conditions. Acetate shows the strongest effect, which may be due to the presence of the acetate 
as stabilizing agent in the original NP dispersion, and formation of cerium-acetate complexes on the particle surface. These results indicate that the oxidation of both ABTS and TMB by nanoceria is $\mathrm{pH}$-dependent, and varied with the conditions used. Therefore, the $\mathrm{pH}$ and ionic composition should be strictly controlled and tested when using this test for NP detection purposes.

\section{Fig. 4.}

\subsubsection{Effect of ionic strength and $\mathrm{HA}$}

Due to the use of nanoceria in many applications, these particles are likely to enter the environment [24]. It is known that metal oxide NPs, including nanoceria can interact with the components of the environment, which can change their surface properties (e.g. through surface adsorption), and alter reactivity [25]. The ionic composition can alter the particle surface through surface adsorption and complexation with charged constituents. In an environmental exposure scenario, electrophoretic mobility is affected by natural organic matter and ionic strength [26, 27]. Particles that are dispersed in optimized conditions may aggregate (or be stabilized) once they are released in the environment [26]. For example, addition of humic acid (HA) was found to reduce particle toxicity in Caenorhabditis elegans as a result of particle coating with the organic matter [27]. Therefore, to establish conditions of use and limitations of this assay in environmental conditions, we have tested the effect of ionic strength and HA on the oxidation of the organic dyes used here as colorimetric probes.

Fig. 5 shows visual images illustrating the effect of $\mathrm{NaCl}$ and $\mathrm{HA}$ at varying concentrations on the oxidation of the two dyes by nanoceria. The particles were dispersed in $\mathrm{NaCl}$ and humic acid solutions before addition of ABTS or TMB. Visual images indicate that oxidation of both ABTS and TMB takes place for nanoceria even when these are exposed to $\mathrm{NaCl}$ and $\mathrm{HA}$. Low concentrations of $\mathrm{NaCl}$ and $\mathrm{HA}$ increased slightly the oxidation of the ABTS dye. This can be explained by a stabilizing effect of HA on nanoceria as a result of particle coating. TMB oxidation was less affected by $\mathrm{NaCl}$, which can be explained by charge repulsion. High $\mathrm{NaCl}$ concentrations, i.e., $1000 \mathrm{mM}$ resulted in inhibition of the dye oxidation which can be

explained by reduced stability of the dispersion at high salt concentrations. An increase in the ionic strength can lead to a decrease in the electrical double layer thickness, which favors particle association increasing agglomeration [28]. The effect of HA was investigated with low (1 and 5 
$\left.\mathrm{mg} \mathrm{L}^{-1}\right)$, medium $\left(10 \mathrm{mg} \mathrm{L}^{-1}\right)$, and high $\left(50 \mathrm{mg} \mathrm{L}^{-1}\right)$ concentrations. The zeta potential (Table S1) of nanoceria in the absence of $\mathrm{HA}$ is $+40.41 \pm 2.8 \mathrm{mV}$. HA carries a negative charge at neutral $\mathrm{pH}$ associated mainly with the ionization of carboxylic groups. After addition of 1, 5, and $10 \mathrm{mg}$

$\mathrm{L}^{-1} \mathrm{HA}$, the zeta potential of the NPs significantly decreased, and the extent of aggregation increased. This effect is seen by the lack of reactivity of the NPs at high HA concentrations (Fig. 5 and Fig. S2). The electrokinetic analysis shows that increasing the concentration of HA decreases the zeta potential to values close to zero for $10 \mathrm{mg} \mathrm{L}^{-1}$ and completely reversed for 50 $\mathrm{mg} \mathrm{L}^{-1}$. These results indicate that $\mathrm{HA}$ has a significant influence on the surface charge of nanoceria, which governs the NP interactions in aqueous systems. Consequently, it can be expected that the adsorbed HA effects the aggregation of nanoceria, and if present at a high concentration it can alter the detection capabilities of the method. Therefore this effect should be considered in the analysis of environmental samples containing large amounts of natural organic material.

\section{Fig. 5.}

\section{Generalizability of the method for detection of different types of nanoceria}

The ability of the method to measure different types of nanoceria and the robustness of the assay were assessed with five different types of commercially available NPs in colloidal and nanopowder forms. Table 2 in SI summarizes the physicochemical properties of the NPs, including size and dispersion medium as provided by the suppliers, and their measured zeta potential values. The colorimetric responses to five different types of commercial NPs using the ABTS and TMB assays are displayed in Fig. 6. All particles provided quantifiable color changes but with varying intensity. In general, particles in colloidal form showed better responses as compared to nanopowders, which can be explained by better dispersion characteristics due to the presence of surface stabilizers. Particles stabilized in acetate showed significantly higher response in the ABTS assay as compared to TMB, while those dispersed in water display an opposite behavior. This might be due to the higher reactivity of the positively charged NPs for ABTS, as compared to the negatively charged NPs. For TMB, NPs with an average size of $5 \mathrm{~nm}$ exhibited a significantly higher response as compared to NPs with the average size of 10-20 nm suggesting stronger oxidation ability due to the small NP size and their negatively charged 
surface. Taken together, these results demonstrate the effectiveness of the assay as a general screening tool for the reactivity of nanoceria particles.

\section{Fig. 6.}

\section{Table 2.}

\section{Selectivity of the method towards other metal oxide NPs}

Our colorimetric method is also found to be selective. To evaluate this property, the method was carried out with varying types of metal oxides, including $\mathrm{Fe}_{2} \mathrm{O}_{3}, \mathrm{TiO}_{2}, \mathrm{Sb}_{2} \mathrm{O}_{3}, \mathrm{ZnO}, \mathrm{SiO}_{2}$, and $\mathrm{Al}_{2} \mathrm{O}_{3}$ under the same conditions and at the same concentration $\left(25 \mathrm{mg} \mathrm{L} \mathrm{L}^{-1}\right)$. The physicochemical characteristics of these oxides are listed in Table S2. Fig. 7 shows visual images and UV-Vis spectra of ABTS and TMB solutions exposed to selected metal oxides. When compared to nanoceria, all other oxides show substantially lower absorbance in reaction with ABTS and TMB. Comparative analysis shows that nanoceria is the only oxide that displayed a strong and well-defined peak in the visible range with a maximum absorbance at 420 and $652 \mathrm{~nm}$. $\mathrm{Fe}_{2} \mathrm{O}_{3} \mathrm{NP}$ was the only other oxide which exhibited a color change. However, this color does not overlap with the spectra of the oxidized ABTS or TMB. The other oxides exhibited a relatively small increase in the visible region (Fig. S3). The stronger response of nanoceria could be due to the oxidation behavior of these NPs for the two organic dyes, as compared to the other oxides. This high selectivity towards nanoceria (three times higher than $\mathrm{Fe}_{2} \mathrm{O}_{3}$ as an example) is expected due to the higher reactivity linked to the dual oxidation state on the surface of nanoceria.

Fig. 7.

\section{Real sample analysis}

In order to evaluate the feasibility of the colorimetric method for the analysis of real samples, nanoceria with a concentration of $10 \mathrm{mg} \mathrm{L}^{-1}$ was spiked into three different environmental water samples, river, beach, and tap water, and analyzed by this method. The recovery was calculated on the basis of calibration curves determined in the aqueous samples, after adjusting the $\mathrm{pH}$. 
Since the method is sensitive to $\mathrm{pH}$, the $\mathrm{pH}$ of the samples was adjusted with $2.5 \%$ acetic acid to maintain the same $\mathrm{pH}$ as that of the solution used to create the calibration curve. The percentage recoveries obtained with the ABTS assay were in good agreement with the spiked amounts of nanoceria (Table 3). This result demonstrates the applicability of the proposed method for detection of nanoceria in aqueous samples.

\section{Table 3.}

\section{Conclusions}

In summary, we have developed and characterized a visual colorimetric assay for screening and reactivity evaluation of nanoceria particles in various environments and established the optimum operational parameters and reaction conditions for this assay. Several types of commercially available nanoceria particles, $\mathrm{pH}$ and reaction conditions were tested to optimize the method and determine the analytical performance characteristics. As a common feature, the method enabled screening of various types of nanoceria. Moreover, the method provided good selectivity as compared with other metal oxides, and demonstrated functionality for detection of NPs in real samples. The use of acetate, citrate, and Tris buffers was found to affect sensitivity of the method. Based on this study, the following general recommendations are provided when considering this assay as a general method for characterizing reactivity of nanoceria particles: (1) the use of water as solvent, (2) avoid the use of solutions containing species that may form surface complexes with cerium such as citrate, acetate, phosphate, etc.; if these species are inherently present in the sample, the effect of these compounds should be established and calibration should be performed in presence of these species; (3) because the physiochemical properties of the particles may change in environmental conditions (e.g. presence of natural organic material and ionic strength), the effect of these parameters should be established. These results can enable further development of methodologies for assessing NPs and NP effects using a simple and cost effective procedure. The method described here is inexpensive, does not require advanced instrumentation and can be used as a widely accessible tool to rapidly assess reactivity in various environments. The work also provides fundamental knowledge on how environmental parameters affect the overall performance of these types of assays, which is essential for the future development of methodologies for nanoparticle quantification purposes. 


\section{Acknowledgment}

This material is based upon work supported by the National Science Foundation under Grant No. CHE-1610281. Any opinions, findings, and conclusions or recommendations expressed in this material are those of the author(s) and do not necessarily reflect the views of the National Science Foundation.

Conflict of Interest

The authors declare no conflict of interest.

\section{References}

[1] J.Y. Ma, H. Zhao, R.R. Mercer, M. Barger, M. Rao, T. Meighan, D. Schwegler-Berry, V. Castranova, J.K. $\mathrm{Ma}$, Cerium oxide nanoparticle-induced pulmonary inflammation and alveolar macrophage functional change in rats, Nanotoxicology 5 (2011) 312-325.

[2] J.Y.C. Ma, S.-H. Young, R.R. Mercer, M. Barger, D. Schwegler-Berry, J.K. Ma, V. Castranova, Interactive effects of cerium oxide and diesel exhaust nanoparticles on inducing pulmonary fibrosis, Toxicol Appl Pharmacol 278 (2014) 135-147.

[3] B. Park, K. Donaldson, R. Duffin, L. Tran, F. Kelly, I. Mudway, J.-P. Morin, R. Guest, P. Jenkinson, Z. Samaras, M. Giannouli, H. Kouridis, P. Martin, Hazard and risk assessment of a nanoparticulate cerium oxide-based diesel fuel additive-A case study, Inhal. Toxicol. 20 (2008) 547-566.

[4] S.J. Snow, J. McGee, D.B. Miller, V. Bass, M.C. Schladweiler, R.F. Thomas, T. Krantz, C. King, A.D. Ledbetter, J. Richards, J.P. Weinstein, T. Conner, R. Willis, W.P. Linak, D. Nash, C.E. Wood, S.A. Elmore, J.P. Morrison, C.L. Johnson, M.I. Gilmour, U.P. Kodavanti, Inhaled diesel emissions generated with cerium oxide nanoparticle fuel additive induce adverse pulmonary and systemic effects, Toxicol. Sci. 142 (2014) 403-417.

[5] A. Hayat, D. Andreescu, G. Bulbul, S. Andreescu, Redox reactivity of cerium oxide nanoparticles against dopamine, J. Colloid Interface Sci. 418 (2014) 240-245.

[6] G. Pulido-Reyes, I. Rodea-Palomares, S. Das, T.S. Sakthivel, F. Leganes, R. Rosal, S. Seal, F. FernandezPinas, Untangling the biological effects of cerium oxide nanoparticles: the role of surface valence states, Scientific reports 5 (2015) 15613.

[7] P. Zhang, Y. Ma, Z. Zhang, X. He, J. Zhang, Z. Guo, R. Tai, Y. Zhao, Z. Chai, Biotransformation of ceria nanoparticles in cucumber plants, ACS Nano 6 (2012) 9943-50.

[8] Y.H. Ma, P. Zhang, Z.Y. Zhang, X. He, J.Z. Zhang, Y.Y. Ding, J. Zhang, L.R. Zheng, Z. Guo, L.J. Zhang, Z.F. Chai, Y.L. Zhao, Where does the transformation of precipitated ceria nanoparticles in hydroponic plants take place?, Environ Sci Technol 49 (2015) 10667-10674. 
[9] K. Midander, P. Cronholm, H.L. Karlsson, K. Elihn, L. Möller, C. Leygraf, I.O. Wallinder, Surface characteristics, copper release, and toxicity of nano- and micrometer-sized copper and copper(II) oxide particles: A cross-disciplinary study, Small 5 (2009) 389-399.

[10] M. Baalousha, Y. Ju-Nam, P.A. Cole, J.A. Hriljac, I.P. Jones, C.R. Tyler, V. Stone, T.F. Fernandes, M.A. Jepson, J.R. Lead, Characterization of cerium oxide nanoparticles-Part 2: Nonsize measurements, Environ Toxicol Chem 31 (2012) 994-1003.

[11] M. Baalousha, P. Le Coustumer, I. Jones, J.R. Lead, Characterisation of structural and surface speciation of representative commercially available cerium oxide nanoparticles, Environ Chem 7 (2010) 377-385.

[12] C. Corredor, M.D. Borysiak, J. Wolfer, P. Westerhoff, J.D. Posner, Colorimetric detection of catalytic reactivity of nanoparticles in complex matrices, Environ Sci Technol 49 (2015) 3611-8.

[13] D. Andreescu, G. Bulbul, R.E. Ozel, A. Hayat, N. Sardesai, S. Andreescu, Applications and implications of nanoceria reactivity: measurement tools and environmental impact, Environ. Sci. Nano 1 (2014) 445458.

[14] N.P. Sardesai, D. Andreescu, S. Andreescu, Electroanalytical evaluation of antioxidant activity of cerium oxide nanoparticles by nanoparticle collisions at microelectrodes, J Am Chem Soc 135 (2013) 16770-16773.

[15] G.V. Lowry, K.B. Gregory, S.C. Apte, J.R. Lead, Transformations of nanomaterials in the environment, Environ Sci Technol 46 (2012) 6893-6899.

[16] M. Tejamaya, I. Römer, R.C. Merrifield, J.R. Lead, Stability of citrate, PVP, and PEG coated silver nanoparticles in ecotoxicology media, Environ Sci Technol 46 (2012) 7011-7017.

[17] A. Hayat, J. Cunningham, G. Bulbul, S. Andreescu, Evaluation of the oxidase like activity of nanoceria and its application in colorimetric assays, Anal Chim Acta 885 (2015) 140-147.

[18] Y. Peng, X. Chen, G. Yi, Z. Gao, Mechanism of the oxidation of organic dyes in the presence of nanoceria, Chem. Commun. 47 (2011) 2916-2918.

[19] A. Asati, S. Santra, C. Kaittanis, S. Nath, J.M. Perez, Oxidase-like activity of polymer-coated cerium oxide nanoparticles, Angew. Chem. Int. Edit. 48 (2009) 2308-2312.

[20] G. Preda, A. Migani, K.M. Neyman, S.T. Bromley, F. Illas, G. Pacchioni, Formation of superoxide anions on ceria nanoparticles by interaction of molecular oxygen with Ce3+ sites, J Phys Chem C 115 (2011) 5817-5822.

[21] L.C. Jones, B.J. Lafferty, D.L. Sparks, Additive and competitive effects of bacteria and Mn oxides on arsenite oxidation kinetics, Environ Sci Technol 46 (2012) 6548-6555.

[22] P.L. Chen, I.W. Chen, Reactive cerium(IV) oxide powders by the homogeneous precipitation method, J Am Ceram Soc 76 (1993) 1577-1583.

[23] S. Singh, T. Dosani, A.S. Karakoti, A. Kumar, S. Seal, W.T. Self, A phosphate-dependent shift in redox state of cerium oxide nanoparticles and its effects on catalytic properties, Biomaterials 32 (2011) 67456753.

[24] N.S. Taylor, R. Merrifield, T.D. Williams, J.K. Chipman, J.R. Lead, M.R. Viant, Molecular toxicity of cerium oxide nanoparticles to the freshwater alga chlamydomonas reinhardtii is associated with supraenvironmental exposure concentrations, Nanotoxicology 10 (2016) 32-41.

[25] E. Sharpe, R. Bradley, T. Frasco, D. Jayathilaka, A. Marsh, S. Andreescu, Metal oxide based multisensor array and portable database for field analysis of antioxidants, Sensors and actuators. B, Chemical 193 (2014) 552-562.

[26] A.A. Keller, H.T. Wang, D.X. Zhou, H.S. Lenihan, G. Cherr, B.J. Cardinale, R. Miller, Z.X. Ji, Stability and aggregation of metal oxide nanoparticles in natural aqueous matrices, Environ Sci Technol 44 (2010) 1962-1967. 
[27] B. Collin, E. Oostveen, O.V. Tsyusko, J.M. Unrine, Influence of natural organic matter and surface charge on the toxicity and bioaccumulation of functionalized ceria nanoparticles in caenorhabditis elegans, Environ Sci Technol 48 (2014) 1280-1289.

[28] P.S. Tourinho, C.A.M. van Gestel, S. Lofts, C. Svendsen, A.M.V.M. Soares, S. Loureiro, Metal-based nanoparticles in soil: Fate, behavior, and effects on soil invertebrates, Environ Toxicol Chem 31 (2012) 1679-1692.

[29] Y. He, Z. Wang, D. Long, Direct visual detection of MnO2 nanosheets within seconds, Anal. Bioanal. Chem. 408 (2015) 1231-1236.

[30] M. Mahmoudi, S.E. Lohse, C.J. Murphy, K.S. Suslick, Identification of nanoparticles with a colorimetric sensor array, ACS Sensors 1 (2015) 17-21.

[31] B. Collin, M. Auffan, A.C. Johnson, I. Kaur, A.A. Keller, A. Lazareva, J.R. Lead, X. Ma, R.C. Merrifield, C. Svendsen, J.C. White, J.M. Unrine, Environmental release, fate and ecotoxicological effects of manufactured ceria nanomaterials, Environ. Sci. Nano 1 (2014) 533-548.

[32] J.T. Dahle, Y. Arai, Environmental geochemistry of cerium: Applications and toxicology of cerium oxide nanoparticles, Int. J. Environ. Res. Public Health 12 (2015) 1253-1278. 
Tables

Table 1. Comparison of our colorimetric assay for the detection of NPs with other reported colorimetric assays for detection of NPs.

\begin{tabular}{|c|c|c|c|c|}
\hline Assay & Performance & $\begin{array}{l}\text { LOD } \\
(\mu \mathrm{g} / \mathrm{mL})\end{array}$ & $\begin{array}{l}\text { LOQ } \\
(\mu \mathrm{g} / \mathrm{mL})\end{array}$ & Ref. \\
\hline $\begin{array}{l}\text { Colorimetric detection of } \\
\text { nanoceria-TMB }\end{array}$ & $\begin{array}{l}\text { - Colorimetric detection of } \mathrm{CeO}_{2} \\
\text { within seconds } \\
\text { - Selective for } \mathrm{CeO}_{2} \text { as compared } \\
\text { with other metal oxide NPs such } \\
\text { as } \mathrm{Fe}_{2} \mathrm{O}_{3}, \mathrm{TiO}_{2}, \mathrm{Sb}_{2} \mathrm{O}_{3}, \mathrm{ZnO} \text {, } \\
\mathrm{SiO}_{2} \text {, and } \mathrm{Al}_{2} \mathrm{O}_{3} \\
\text { - Environmental water samples: } \\
\text { river, beach, and tap water }\end{array}$ & $\begin{array}{l}0.1836 \\
\text { (for } \\
\mathrm{CeO}_{2} \text { ) } \\
0.0424 \\
(\text { for } \\
\left.\mathrm{CeO}_{2}\right)\end{array}$ & $\begin{array}{l}0.1412 \\
\text { (for } \\
\mathrm{CeO}_{2} \text { ) }\end{array}$ & $\begin{array}{l}\text { This } \\
\text { study }\end{array}$ \\
\hline $\begin{array}{l}\text { Colorimetric Detection of } \\
\text { Catalytic Reactivity of } \\
\text { Nanoparticles in Complex } \\
\text { Matrices }\end{array}$ & $\begin{array}{l}\text { - Responds to a wide range of } \\
\text { metals (e.g., Ag and Au) and } \\
\text { metal oxide NPs } \\
\text { - Environmental water (e.g., lake } \\
\text { water, NOM) and biological } \\
\text { matrices (e.g., artificial urine, } \\
\text { mouse serum) }\end{array}$ & $\begin{array}{l}0.089- \\
1.759 \text { (for } \\
\text { AuNPs } \\
\text { spiked in } \\
\text { various } \\
\text { sample } \\
\text { types) }\end{array}$ & $\begin{array}{l}0.526- \\
5.864 \\
\text { (for } \\
\text { AuNPs } \\
\text { spiked in } \\
\text { various } \\
\text { sample } \\
\text { types) }\end{array}$ & {$[12]$} \\
\hline $\begin{array}{l}\text { Direct visual detection of } \\
\mathrm{MnO}_{2} \text { nanosheets within } \\
\text { seconds }\end{array}$ & $\begin{array}{l}\text {-Demonstrated for } \mathrm{MnO}_{2} \\
\text { nanosheets, } \mathrm{Mn}^{2+} \text { ions, TMA } \mathrm{OH} \text {, } \\
\mathrm{H}_{2} \mathrm{O}_{2} \text {, graphene oxide }(\mathrm{GO}) \text {, and } \\
\text { graphitic carbon nitride }\left(\mathrm{g}-\mathrm{C}_{3} \mathrm{~N}_{4}\right) \\
\text { nanosheets } \\
\text { - Real lake water samples }\end{array}$ & $\begin{array}{l}2.00(\text { for } \\
\left.\mathrm{MnO}_{2}\right)\end{array}$ & --- & [29] \\
\hline $\begin{array}{l}\text { Identification of } \mathrm{Au} \text { NPs } \\
\text { with a colorimetric sensor } \\
\text { array }\end{array}$ & $\begin{array}{l}\text { - Colorimetric sensor array } \\
\text { technique was developed for the } \\
\text { detection } \mathrm{Au} \text { nanospheres, Au } \\
\text { nanorods, and multifunctional } \\
\text { carbon nanospheres. } \\
\text { - No real samples were tested }\end{array}$ & $\begin{array}{l}0.1-1.0 \\
\text { (for Au } \\
\text { NPs in } \\
\text { aqueous } \\
\text { solutions) }\end{array}$ & --- & {$[30]$} \\
\hline
\end{tabular}


Table 2: Characteristics of the different types of commercially available nanoceria particles tested.

\begin{tabular}{|c|c|c|c|c|c|}
\hline Sample & Source & Supplier & Nature of NPs & $\begin{array}{l}\text { NPs Size } \\
(\mathrm{nm})\end{array}$ & $\begin{array}{l}\text { Zeta Potential } \\
(\mathrm{mV}) \text {-measured }\end{array}$ \\
\hline A & Commercial & $\begin{array}{l}\text { Alfa Aesar, } \\
\# 40125\end{array}$ & $\begin{array}{l}\text { Colloidal, } \\
20 \% \text { in } \mathrm{H}_{2} \mathrm{O} \text {, dispersion } \\
\text { stabilized in } 0.4 \mathrm{M} \text { acetate }\end{array}$ & $10-20$ & $+41.41 \pm 2.8$ \\
\hline B & Commercial & $\begin{array}{l}\text { Alfa Aesar, } \\
\# 47240\end{array}$ & $\begin{array}{l}\text { Colloidal, } \\
20 \% \text { in } \mathrm{H}_{2} \mathrm{O} \text {, nanoparticle } \\
\text { dispersion, high } \mathrm{pH}\end{array}$ & $<5$ & $-16.40 \pm 2.12$ \\
\hline $\mathrm{C}$ & Commercial & $\begin{array}{l}\text { Sigma-Aldrich, } \\
\text { \#MKBD9924 }\end{array}$ & $\begin{array}{l}\text { Colloidal, } \\
10 \mathrm{wt} \% \text { dispersion in water }\end{array}$ & $<25$ & $-4.33 \pm 0.84$ \\
\hline $\mathrm{D}$ & Commercial & $\begin{array}{l}\text { SkySpring, } \\
\# 2110 \mathrm{CG}\end{array}$ & nanopowder & $10-30$ & $-17.30 \pm 0.54$ \\
\hline $\mathrm{E}$ & Commercial & $\begin{array}{l}\text { Sigma-Aldrich, } \\
\text { \# MKBK5915V }\end{array}$ & nanopowder & $<25$ & $-22.33 \pm 0.84$ \\
\hline
\end{tabular}

Table 3. Application of the method to nanoceria detection in environmental water using the ABTS assay.

\begin{tabular}{llll}
\hline Sample & $\begin{array}{l}\text { River } \\
\text { water }\end{array}$ & $\begin{array}{l}\text { Beach } \\
\text { water }\end{array}$ & $\begin{array}{l}\text { Tap } \\
\text { water }\end{array}$ \\
\hline Spiked nanoceria $\left(\mathbf{m g ~ L ~}^{-\mathbf{1}}\right)^{\mathbf{a}}$ & 10 & 10 & 10 \\
Recovered nanoceria $\left(\mathbf{m g ~ L}^{-\mathbf{1}}\right)^{\mathbf{b}}$ & 9.45 & 9.21 & 9.65 \\
RSD (\%) & 0.7 & 3.8 & 4.2 \\
Recovery (\%) & 94.5 & 92.1 & 96.5 \\
\hline
\end{tabular}

\footnotetext{
${ }^{\mathrm{a}}$ The concentration was chosen to match the range of nanoceria concentration found in the environment [31, 32].

${ }^{b}$ The concentration was calculated on the basis of calibration curve performed in water
} 


\section{Figure captions}

Figure 1. Detection principle of nanoceria based on the oxidation of (A) ABTS and (B) TMB and their corresponding UV-Vis spectra. Inset pictures show the visual color change before and after addition of nanoceria to ABTS and TMB solutions. (C) HRTEM of the particles used to optimize the assay.

Figure 2. Spectroscopic results showing concentration dependent changes for ABTS (A and B) and TMB (C and $\mathbf{D})$ with varying the concentration of nanoceria from a to $\mathrm{g}$ : $0.78,1.65,3.12$, 6.50, 12.50, 25.0, and 50.0 mg/L. B and D: corresponding calibration curves and linear ranges for $(\mathrm{n}=3)$ measurement. Reaction time for ABTS and TMB was 5 and 15 minutes, respectively.

Figure 3. Effect of reaction time on the absorbance spectra of A) ABTS (0.13 mM) and B) TMB $(1.3 \mathrm{mM})$ dyes upon addition of nanoceria in deionized water, $(\mathrm{n}=3)$.

Figure 4. Effect of $\mathrm{pH}$ and buffer conditions on the detection of nanoceria $(25 \mathrm{mg} / \mathrm{L})$ using the A) ABTS and B) TMB assays. The buffers from left to right: acetate $(0.2 \mathrm{M})$ with $\mathrm{pH}$ of: 3.6, 4, 4.5, 5, and 5.5; citrate (0.2 M) with $\mathrm{pH}$ of: 3.4, 5.5, 6, and 7.4; and Tris (0.2 M) with pH of: 7.5, 8.0, 8.5, and 9.0.

Figure 5. Effect of ionic strength (left) and humic acid (right) on the colorimetric response in the absence (A) and presence of ABTS (B) and TMB (C). Particles $\left(25 \mathrm{mgL}^{-1}\right)$ were exposed to $\mathrm{NaCl}$ solutions at concentration of 1, 10, 100, and $1000 \mathrm{mM}$, and HA solutions at concentration of $1,5,10$, and $50 \mathrm{mg} \mathrm{L}^{-1},(\mathrm{n}=3)$.

Figure 6. Comparative results of the colorimetric response to different types of commercially available nanoceria using the ABTS (A) and TMB (B) assays. The nanoceria tested are: A) 10-20 $\mathrm{nm}, 20 \%$ in $\mathrm{H}_{2} \mathrm{O}$, colloidal in $0.4 \mathrm{M}$ acetate, $\left.\mathrm{B}\right)<5 \mathrm{~nm}, 20 \%$ in $\mathrm{H}_{2} \mathrm{O}$, colloidal, high $\left.\mathrm{pH}, \mathrm{C}\right)<25$ $\mathrm{nm}, 10 \mathrm{wt} \%$ in $\mathrm{H}_{2} \mathrm{O}$, D) 10-30 nm, nanopowder, E) <25 nm, nanopowder, $(\mathrm{n}=3)$.

Figure 7. The selectivity of the proposed method towards nanoceria. Colorimetric response before (A and B) and after ( $\mathbf{C}$ and D) addition of metal oxides to ABTS and TMB solutions (E and F). The concentration of the oxides is $25 \mathrm{mg} \mathrm{L}^{-1},(\mathrm{n}=3)$. 


\section{Figures}
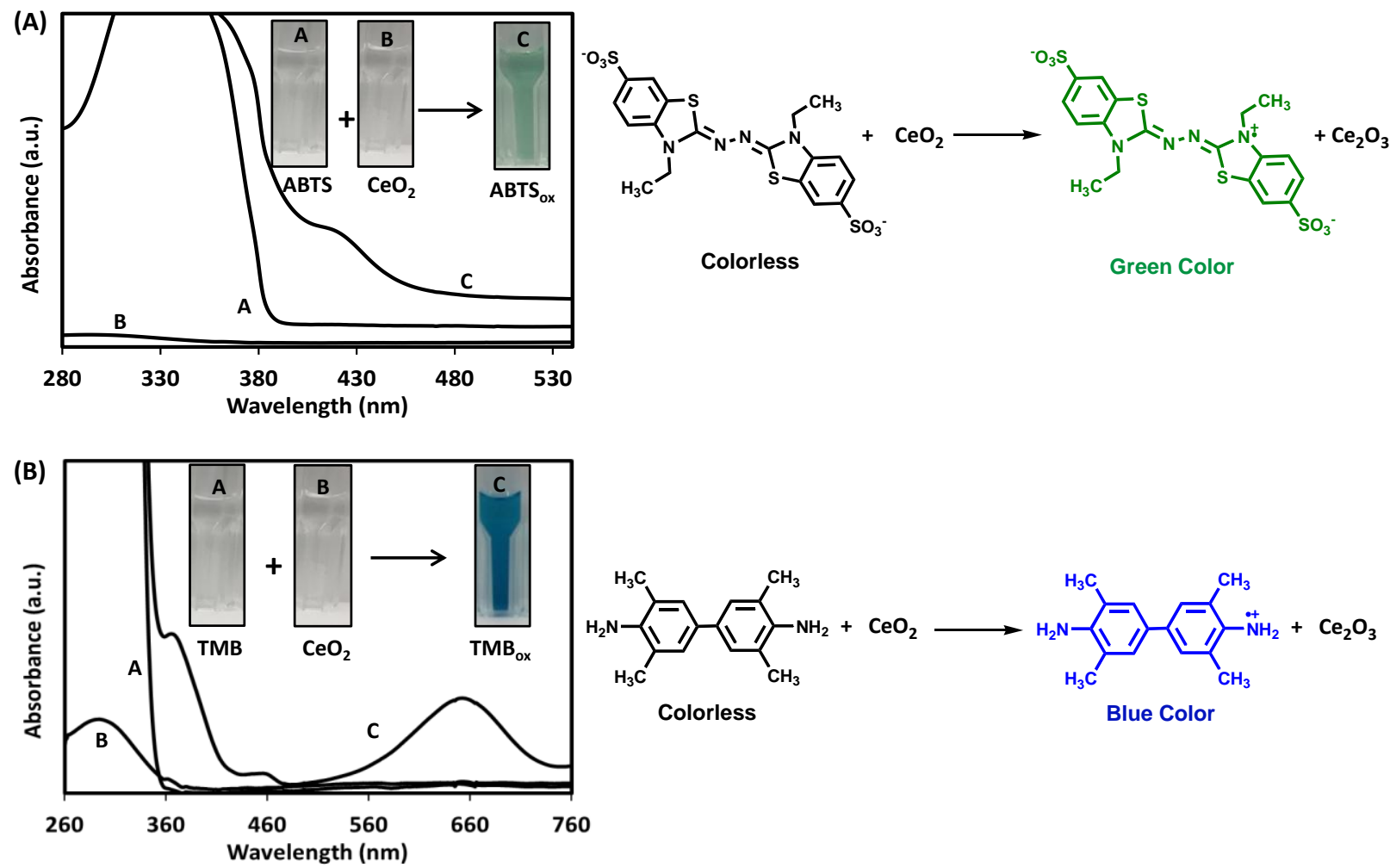

(C)

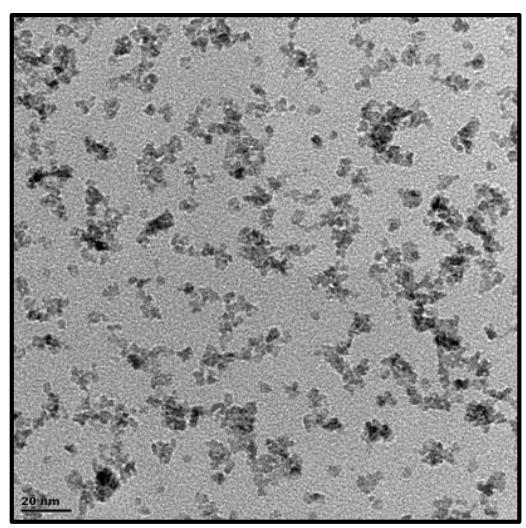

Fig. 1. 

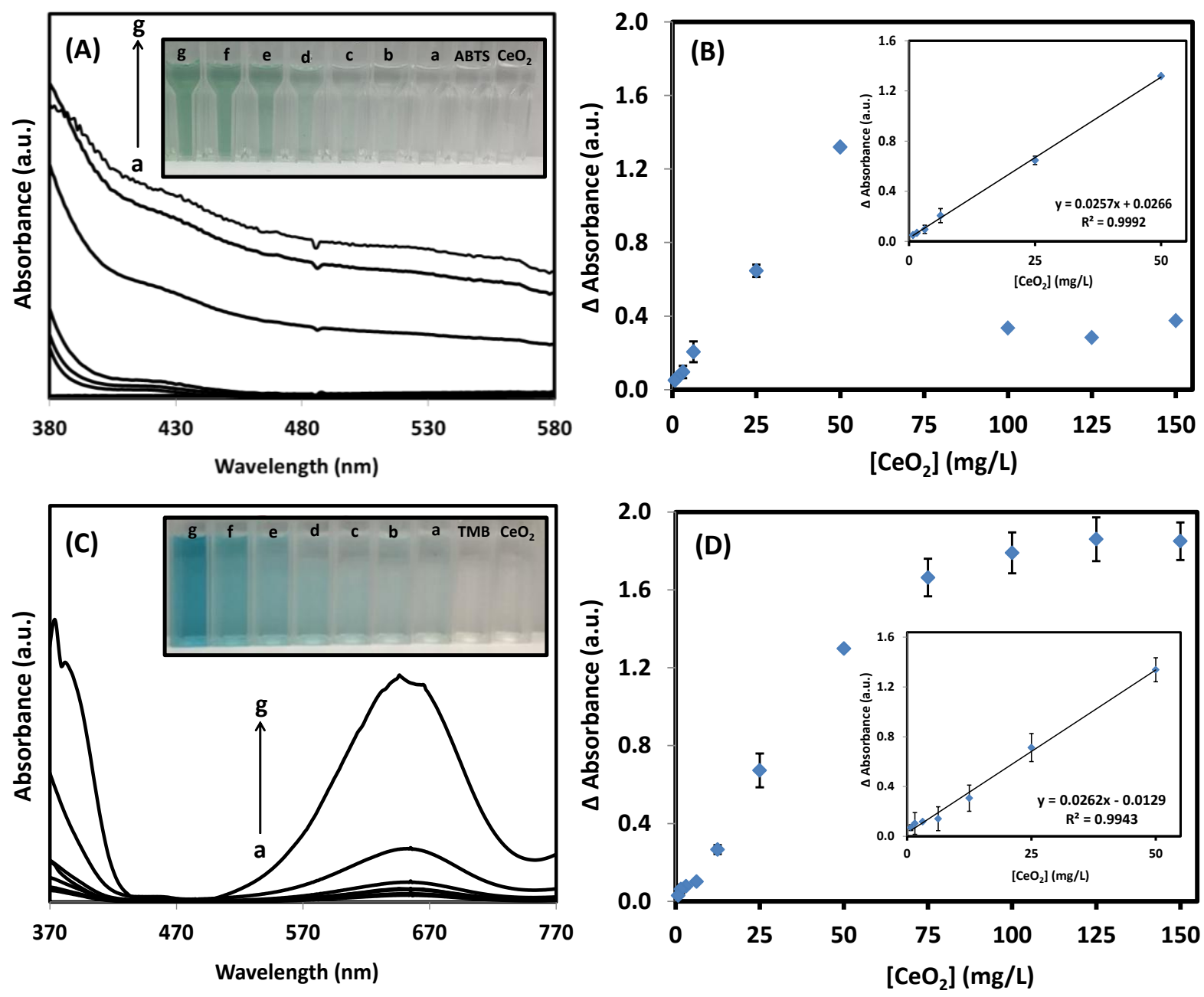

Fig. 2. 

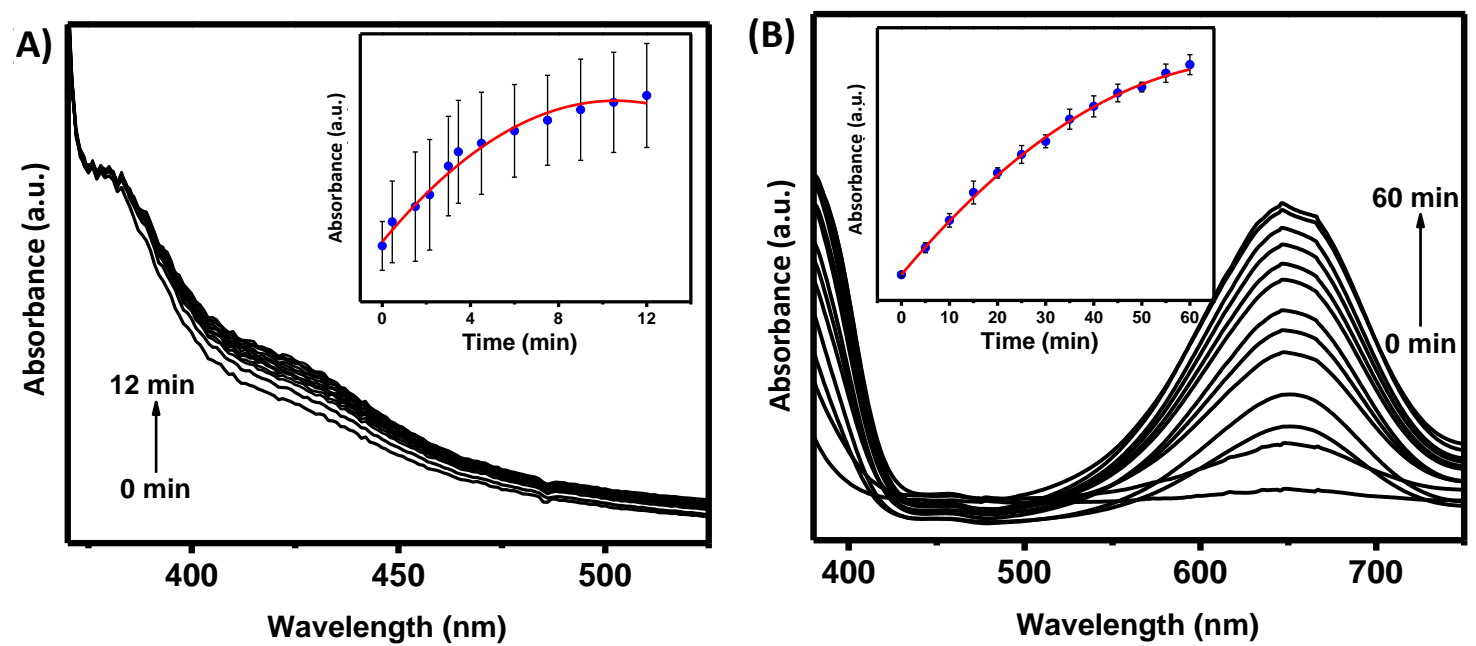

Fig. 3. 
(A)
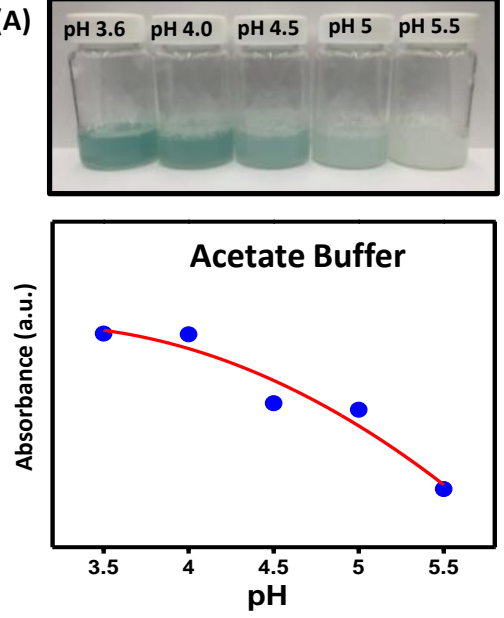

(B)
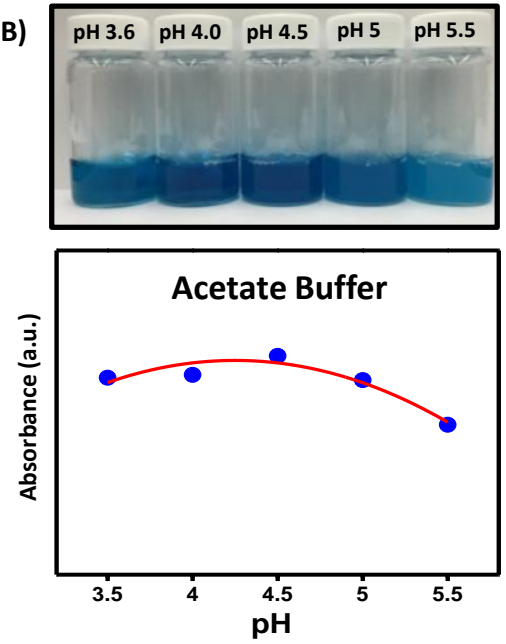
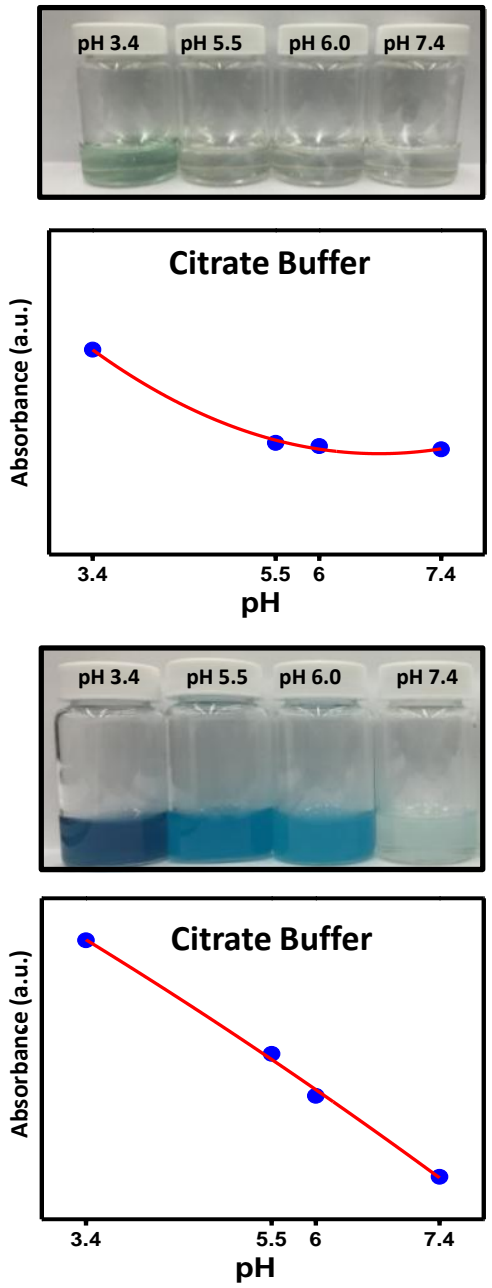
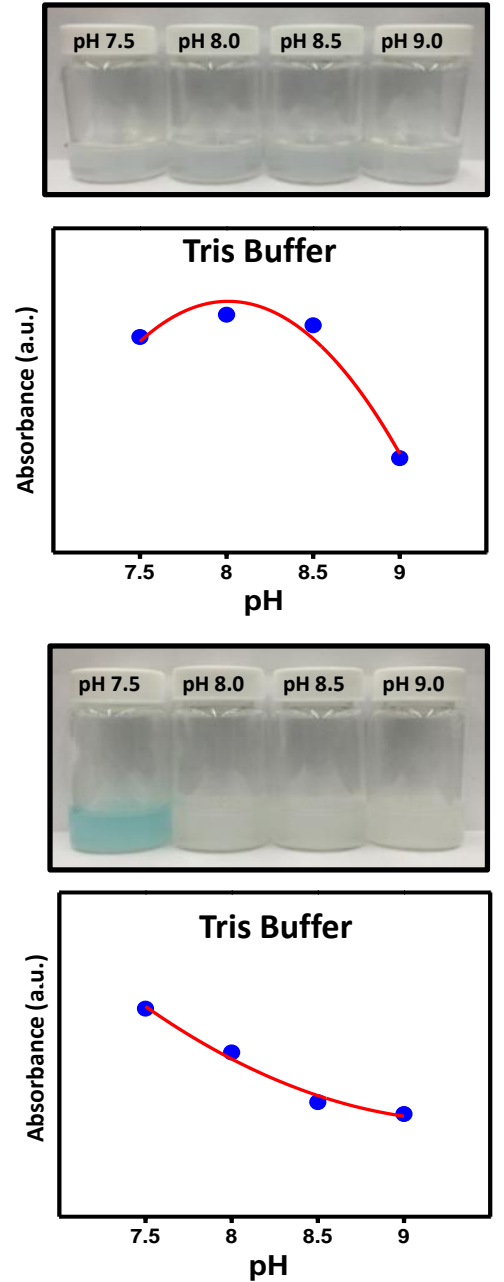

Fig. 4. 
(A)

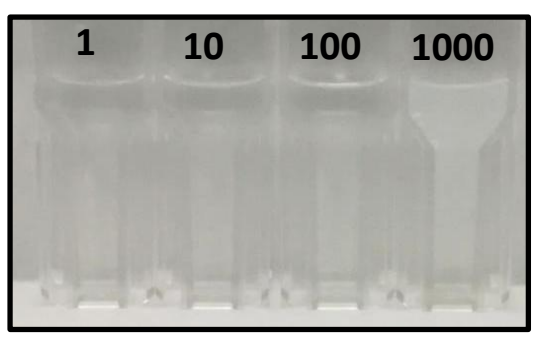

$\mathrm{mM} \mathrm{NaCl}$ (A)

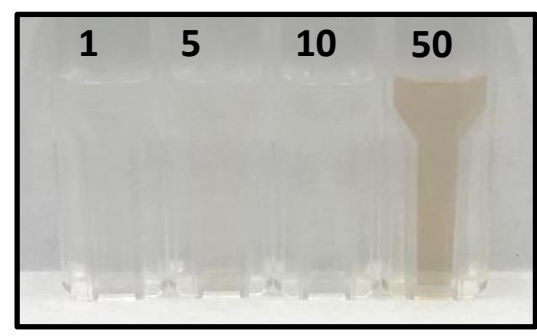

(B)

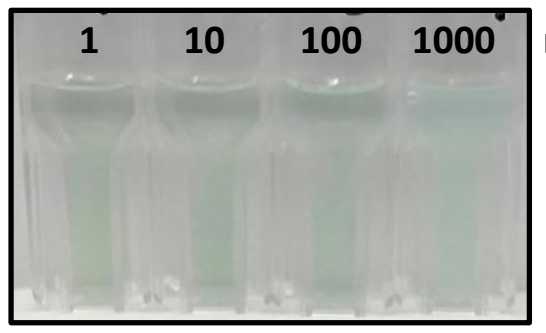

$\mathrm{mM} \mathrm{NaCl}$ (B)

(B)

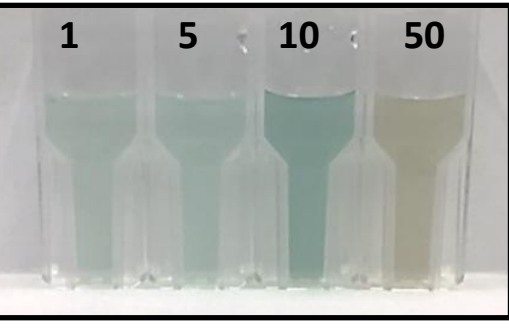

(C)

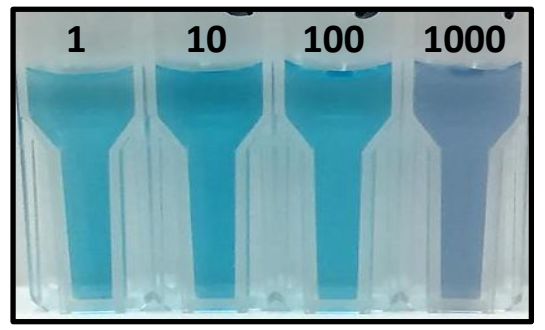

$\mathrm{mM} \mathrm{NaCl}$ (C)

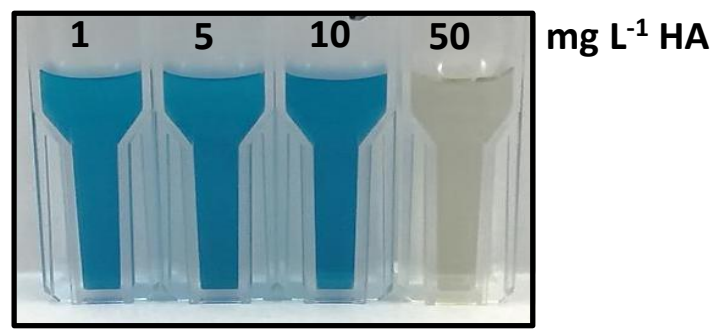

Fig. 5. 

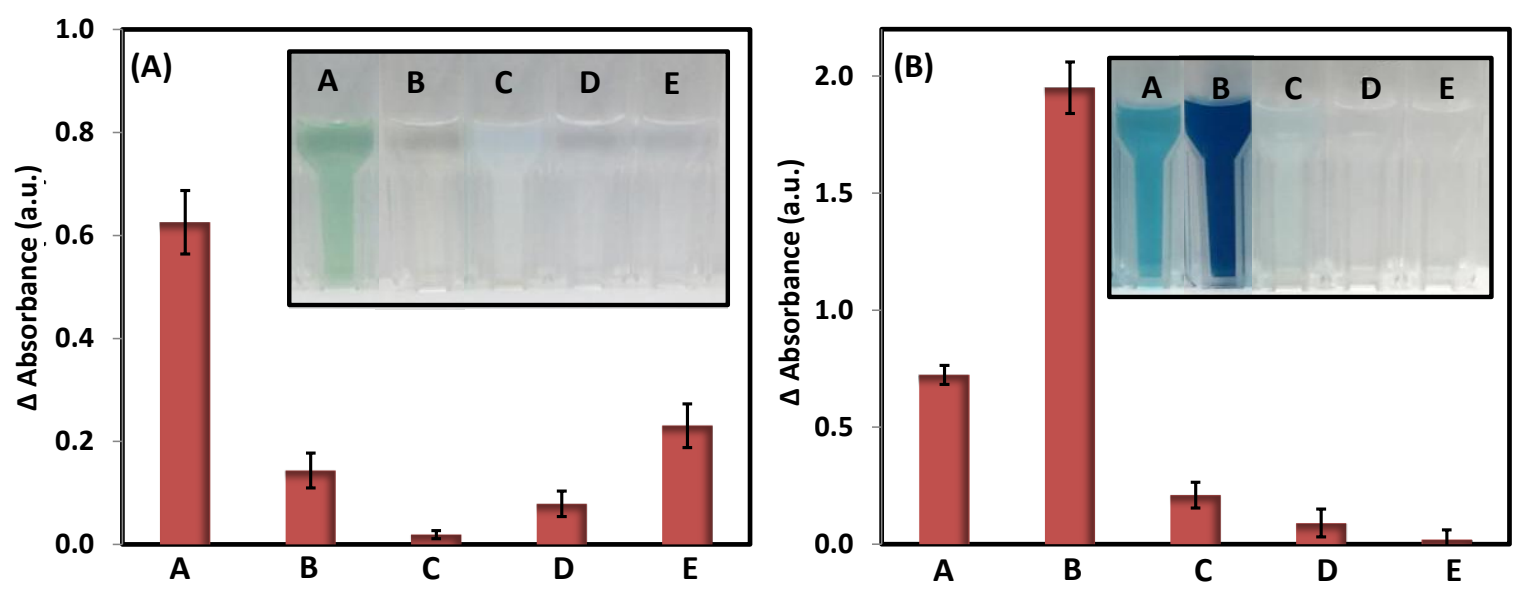

Fig. 6. 


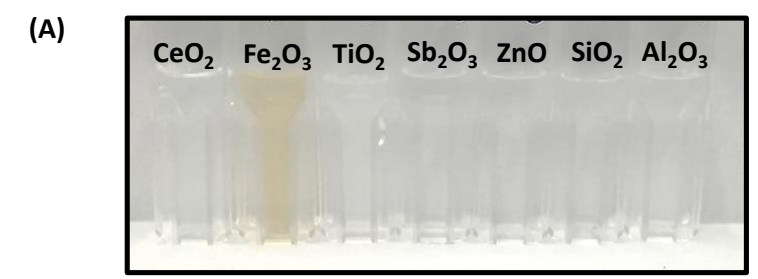

(B)
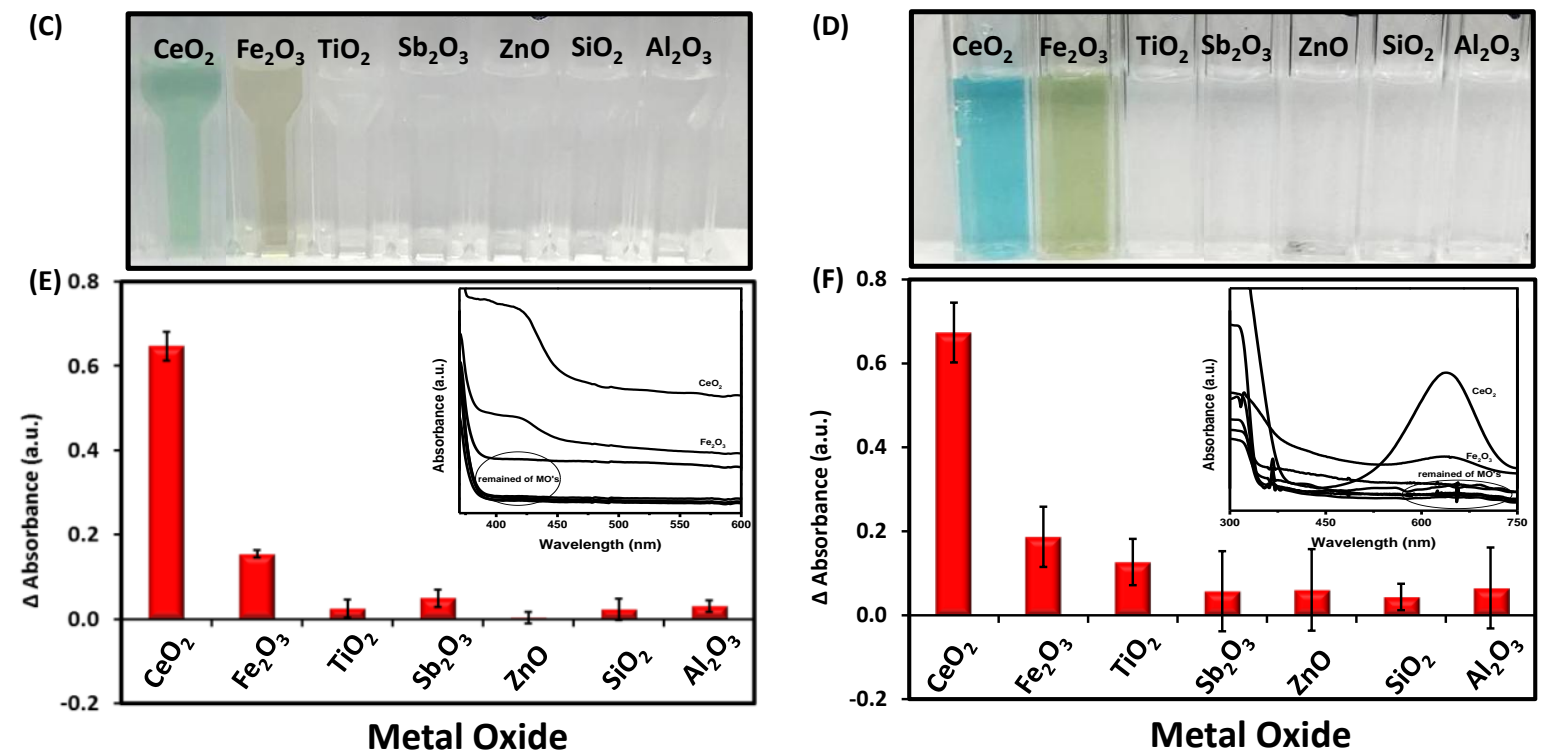

Fig. 7. 


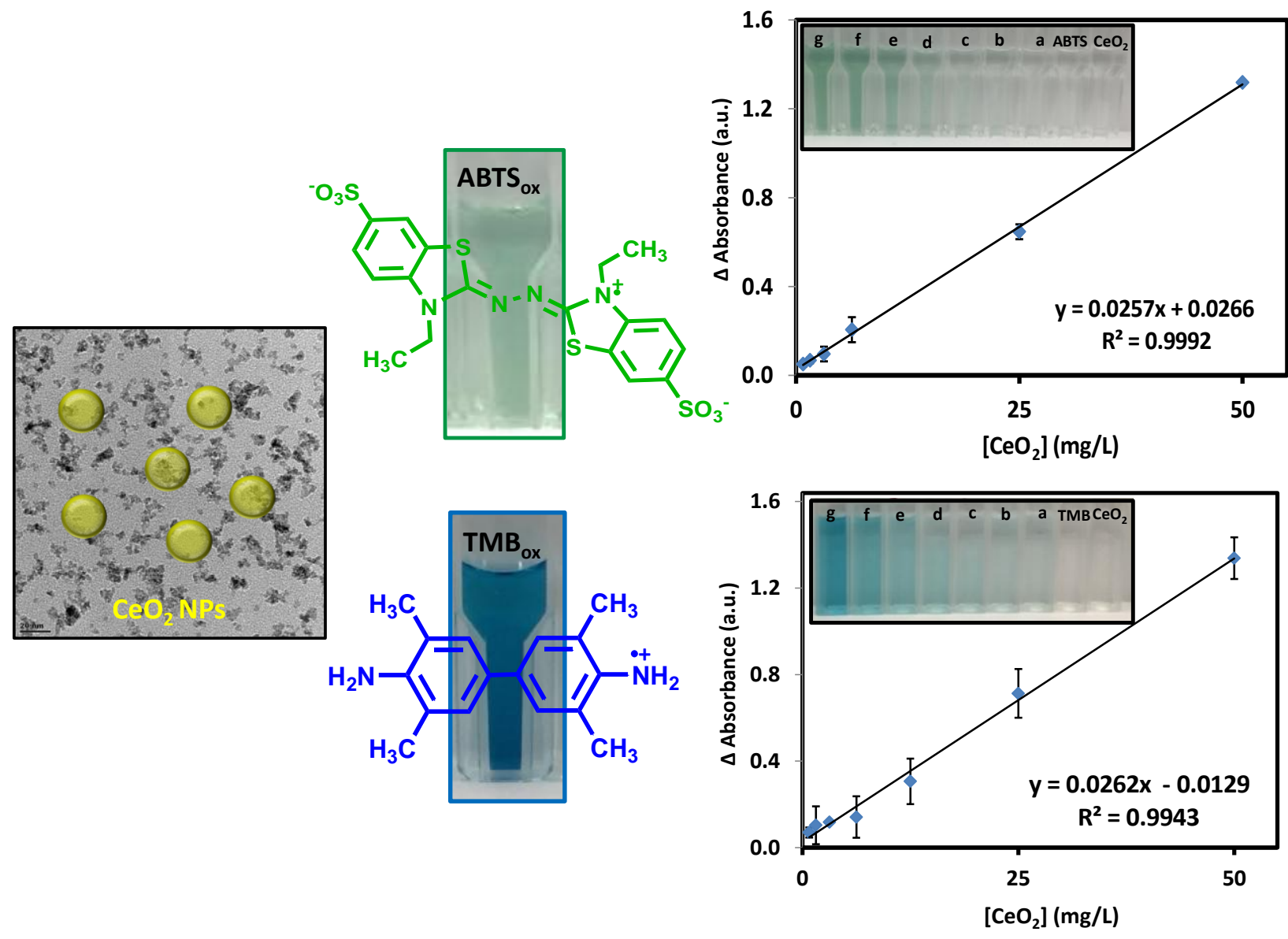

